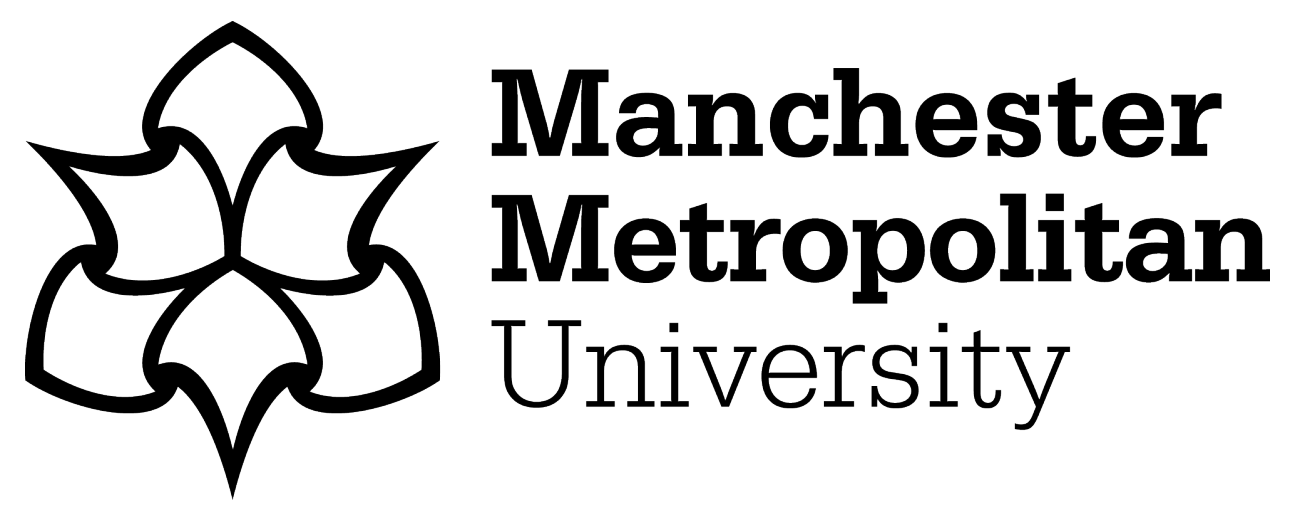

Brearley, FQ (2012) Ectomycorrhizal Associations of the Dipterocarpaceae. Biotropica, 44 (5). pp. 637-648. ISSN 0006-3606

Downloaded from: https://e-space.mmu.ac.uk/839/

Version: Accepted Version

Publisher: Wiley

DOI: https://doi.org/10.1111/j.1744-7429.2012.00862.x

Please cite the published version 
LRH: Brearley

RRH: Dipterocarpaceae Mycorrhizas

\section{Ectomycorrhizal Associations of the Dipterocarpaceae}

Francis Q. Brearley ${ }^{1}$

School of Science and the Environment, Manchester Metropolitan University, Chester Street, Manchester, M1 5GD, U.K.

Received 16 April 2011; revision accepted 10 October 2011.

${ }^{1}$ Corresponding author; e-mail: f.q.brearley@mmu.ac.uk 


\section{ABSTRACT}

3

4 Dipterocarps are one of the most important tree families in the lowland forests of

5 Southeast Asia and are somewhat unusual among tropical trees in that they form

6 ectomycorrhizal (EcM) symbiotic root-inhabiting fungal associations. It has been

7 hypothesised that dipterocarps have been partnered in this mutualistic association prior

8 to the separation of Gondwana. Under many conditions EcMs form rapidly on

9 dipterocarp seedlings through inocula present in the soil, although few studies have

10 been conducted to provide evidence that they improve seedling establishment and

11 performance. There are hundreds of EcM species associated with dipterocarps. Fungal

12 fruit body surveys suggest the most important families are Amanitaceae, Boletaceae and

13 Russulaceae, although Thelephoraceae also become numerically important when root

14 tips are examined. EcM communities are affected by various biotic and abiotic factors,

15 as well as anthropogenic perturbations, and I examine the importance of these in

16 structuring EcM communities.

17

18 Key words: fungi; mycorrhiza; molecular identification; mutualism; seedling

19 performance; soils; symbiosis.

20 
23 Their tree communities are dominated by members of the Dipterocarpaceae (Proctor et al. 1983, Newman et al. 1996, 1998; Brearley et al. 2004, Slik et al. 2009). In addition to their ecological dominance, dipterocarps also provide significant economic resources, producing not only valuable timber, but also a number of non-timber forest products such as oils, nuts and resins (Shiva \& Jantan 1998). With continued degradation of forests in the Southeast Asian region, there is an increased interest in establishing plantations of forest trees and promoting restoration strategies (Kettle 2010). Due to their important ecological and economic roles, understanding the growth and regeneration of dipterocarps is an important research priority. The role of light and nutrients in seedling growth and performance has received much attention in this regard; that of mycorrhizas has often been invoked but much less studied.

Mycorrhizas are an intimate symbiotic association between specialised root-inhabiting fungi and the roots of living plants; they are generally considered mutualistic as benefits are accrued by both partners. The plant provides the fungus with carbon derived from its photosynthetic activity and, in return, the fungus can improve nutrient uptake, growth, water relations, pathogen and heavy metal resistance of the plant (van der Heijden \& Sanders 2002, Smith \& Read 2008, and references therein). Mycorrhizas are important as they extend roots' nutrient depletion zones, especially for poorly mobile inorganic nutrients such as phosphorus $(\mathrm{P})$ that are found at especially low concentrations in many tropical soils (Proctor et al. 1983, Brearley 2003, Brearley et al. 2004, Paoli et al. 2006). Early work on mycorrhizas focused on this nutrient uptake capability of the symbiosis but we are now aware of the multifunctional role played by mycorrhizas in enhancing protection against a number of environmental stresses, and it is clear that this role acts 
47 independently of improved plant nutrition (Read 1986, Newsham et al. 1995). This led

48 Read (1998) to propose a definition of mycorrhizas as 'structures in which a symbiotic

49 union between fungi and plant roots leads to increases in fitness of one or both partners'. An estimated 95 percent of plant species are in characteristically mycorrhizal

51 families (Read 1999) and they are found in almost every terrestrial ecosystem. The

52 arbuscular mycorrhizal (AM) symbiosis, formed by members of the Glomeromycota, is

53 the most abundant type of mycorrhiza, and most tropical trees form AMs (de Alwis \&

54 Abeynayake 1980, St. John 1980, Chalermpongse 1987, Newbery et al. 1988, Moyersoen 1993, Béreau et al. 1997, McGuire et al. 2008). An important, and often dominant, minority of tropical tree families, including the Dipterocarpaceae, form EcMs (Figure 1) that are mostly members of the Basidiomycota or Ascomycota. EcM trees in the tropics often form monodominant stands (Connell \& Lowman 1989, Henkel 2003, Peh et al. 2011) but the dipterocarps rarely do so.

In this review, I outline the current state of knowledge of dipterocarp EcM fungi and their role in tropical ecosystems. The vast majority of current work is from the Asian dipterocarps and studies on these species, therefore, form most of the body of this review. I focus on the role of EcMs in improving seedling growth and performance (see also Brearley 2011), and on EcM species diversity and factors affecting patterns of diversity. I start with a brief history of dipterocarp mycorrhizal research and the

67 biogeographical insights it has provided. I then examine the role of EcMs in the growth and performance of dipterocarp seedlings under both nursery and field conditions. The range of fungal species that form EcMs on dipterocarps is then explored, and I outline the how new molecular techniques have improved our knowledge of dipterocarp EcMs.

71 Key determinants of EcM community dynamics, including various biotic and abiotic 
72 factors and perturbations, are then evaluated. Colonization by other symbiotic fungi is

73 briefly assessed. The review concludes with some thoughts on future research priorities.

74

\section{BRIEF HISTORY OF DIPTEROCARP MYCORRHIZAL RESEARCH}

Van Roosendael and Thorenaar (1924) and de Voogd (1933) both noted the presence of

77

'mycorrhizas' on the roots of dipterocarp seedlings although it is not clear exactly what they saw as they did not publish pictures or record further observations. Although John Corner (1972, among others) noted EcM fungal fruiting bodies in dipterocarp forests, he attributed this to the presence of the Fagaceae (long known to be EcM in temperate regions), and it was not until 1966 that Singh recorded that dipterocarps, in common with a few other tropical angiosperms (Peyronel \& Fassi 1957), formed EcMs. Early work (1960s to 1980s) simply noted various dipterocarp species as forming EcM associations (Singh 1966, de Alwis \& Abeyneyake 1980, Alexander \& Högberg 1986) and made cursory attempts to ascertain which fungal species were putative EcM formers (Hong 1979). The first attempts at in vitro synthesis of EcMs were not reported until the late 1980s (Louis \& Scott 1987, de Alwis \& Abeyneyake 1988) along with early reports of increased growth of inoculated seedlings also around this time (Hadi \& Santoso 1988, Santoso 1988). In the late 1980s and early 1990s, Lee Su See's work advanced EcM research by examining functional aspects of the symbiosis e.g., interactions of EcMs with nutrients to determine seedling growth (Lee \& Alexander 1994), and the succession of EcM fungi on seedlings (Lee \& Alexander 1996) and her collaborations with Frédéric Lapeyrie advanced inoculation techniques with a range of fungal species (Yazid et al. 1994, 1996; Lee et al. 1995b, 2008). Throughout the 1990s to mid 2000s the IUFRO-SPDC funded BIO-REFOR conferences led to more work being published in the region; although some of these papers were valuable, many had limited value due 
97 to inappropriate design or lack of detail in reporting (Brearley 2011). The involvement

98 of Roy Watling in the 1990s started to build knowledge of the fungal flora of Peninsular

99 Malaysia from the strong foundations laid by Corner (Watling \& Lee 1995, 1998, 2007;

100 Watling et al. 1995a, 1998, 2002, 2006; Lee et al. 2002a, 2003; Lee 2005).

101 Subsequent eco-physiological work examined how EcM communities were affected by

102 biotic and abiotic perturbations (Brearley 2006, Brearley et al. 2003, 2007) and

103 examined the role of EcMs in organic nitrogen acquisition (Brearley et al. 2003). The

104 first molecular study of dipterocarp EcM communities appeared in 2003

105 (Sirikantaramas et al. 2003), and since then there have been a few more (Moyerseon

106 2006, Yuwa-Amornpitak et al. 2006, Tedersoo et al. 2007a, Peay et al. 2010) although

107 until the comprehensive study by Peay et al. (2010) these had mostly focused on rare or

108 outlying members of the Dipterocarpaceae. Most recently, advances based on early

109 nursery-based inoculation studies have been extended to the field performance of

110 dipterocarp seedlings (Brearley 2003, Turjaman et al. 2007, Lee et al. 2008, Tata et al.

$1112010)$.

112

INSIGHTS FROM ECTOMYCORRHIZAS INTO THE ORIGINS AND

BIOGEOGRAPHY OF THE DIPTEROCARPACEAE

115 The biogeography of the Dipterocarpaceae is interesting as the vast majority of the 520

116 or so species are found in Southeast Asia with around 30 species in Africa and two in

117 South America (Dayanandan et al. 1999). The consistent EcM status of

118 Dipterocarpaceae in Southeast Asia, the dipterocarp sub-family Monotoideae in Africa

119 and the Neotropical genus Pakaraimaea, suggests a common EcM ancestor and

120 evolution of the EcM habit before continental separation of Gondwana. Doucousso et

121 al. (2004) placed the origin of the EcM habit at least 88 million yr ago, prior to the 
separation of Madagascar and India, as the closest relative of the Dipterocarpaceae

123 sharing a common ancestor, the Madagascan Sarcoleanaceae, are also EcM. The more recent discovery by Moyersoen (2006) that Pakaraimaea dipterocarpacea, basal in the dipterocarp clade, is also EcM suggests an earlier origin of the EcM habit to around 135 million yr ago before the continental separation of South America from Africa. This predates the earliest EcM fossils, which are around 50 million yr old (LePage et al. 1997, Beimforde et al. 2011) and sets the evolution of the EcM habit on the same timescale as the rise and radiation of the angiosperms. The evidence is not conclusive, however, as Alexander (2006) suggests that the Dipterocarpaceae might not have been EcM prior to the separation of the continents but became EcM at a later stage.

EFFECTS OF ECTOMYCORRHIZAL COLONIZATION ON THE GROWTH AND PERFORMANCE OF DIPTEROCARP SEEDLINGS

The importance of EcMs for dipterocarp seedling growth and performance has been reviewed recently (Brearley 2011) and so this topic is only briefly addressed here.

137 Numerous nursery experiments show that EcMs improve dipterocarp seedling growth 138 and nutrient uptake (Hadi \& Santoso 1988, 1989; Santoso 1988, 1991; Lee \& Alexander 1994; Yazid et al. 1994, 1996; Turjaman et al. 2005, 2006; Lee et al. 2008) and facilitate access to organic $\mathrm{N}$ sources (Brearley et al. 2003). These experiments have often been conducted with exotic EcM isolates, as it has proved difficult to isolate fungi

142 from fruit bodies found in Southeast Asian forests. Simple observations and

143 experiments have also correlated seedling biomass (Turner et al. 1993), relative growth rates (Saner et al. 2011) and foliar P concentrations (Lee \& Lim 1989) with percentage

145 EcM colonization. It should be reiterated, however, that most of the above experiments 
146 have been conducted under controlled nursery conditions, sometimes with only a single

147 species of EcM inoculated onto the roots of the experimental seedlings.

149 Experiments under field conditions are rarer and seedlings do not show as clear a 150 response to the presence of EcMs when planted in natural forest or rubber agroforest 151 (Brearley 2003, Tata et al. 2010). For example, there was no clear biomass response of Hopea nervosa and Parashorea tomentella seedlings to a reduction in EcM colonization by fungicide addition, though foliar nutrient concentrations did show a decline (Brearley 2003). There are significant challenges, however, in conducting field experiments, the major one being that it is very difficult to create truly non-mycorrhizal controls.

156 Similarly, for inoculation experiments, such as that of Tata et al. (2010), where EcM 157 inoculum is already present in the soil, the benefits of inoculating seedlings are not 158 clear, especially if the inoculated EcM species does not remain on the roots of the seedlings. In contrast, the work of Turjaman et al. (2007) in degraded peat swamp forest did show improved growth of inoculated dipterocarp seedlings when out-planted in a 161 degraded peat swamp area. This suggests that EcMs are most likely to benefit seedling

162 performance when seedlings are planted in degraded areas where suitable EcM inoculum is not available, such as mine tailings (Lee et al. 2008), burnt areas (Akema et al. 2009), degraded peatlands (Turjaman et al. 2007) or areas previously used for agriculture (Ingleby et al. 2000). In many cases, such as in logged forest, EcM colonization occurs rapidly and naturally (Lee \& Alexander 1996, Lee et al. 1996b) and

167 under such conditions inoculation might not be worthwhile (Brearley 2011).

168 Furthermore, inoculated EcM species do not always remain on the seedling roots, for example Chang et al. $(1994,1995)$ showed that a species of Pisolithus in Malaysian 
170 inoculation experiments had mostly disappeared from roots six months after colonised

171 seedlings were planted into the field.

172

173 Clearly, we need to further evaluate the growth and survival of EcM versus non-EcM

174 seedlings in the field, as positive responses to EcMs in simplified nursery environment

175 are unlikely to be representative of those found in forest sites. In addition, we need an

176 effective way to create truly non-mycorrhizal control seedlings for comparisons with

177 experimental seedlings.

178

179 NURSING ROLE OF PARENT TREES

180 Early colonization of dipterocarps is dependent upon mycorrhizal connections made

181 with parent trees (Alexander et al. 1992), but the importance of these connections for carbon transfer between plants via hyphal connections of non host-specific fungi, which has been demonstrated by Simard et al. (1997) in boreo-temperate forests, is not clear.

184 Potentially, movement of compounds through hyphal connections could provide an

185 important carbon subsidy to maintain dipterocarp seedlings in a light-limited state in the

186 forest understory. Two experiments conducted in Malaysian Borneo have shown that

187 inter-individual connections by EcM hyphal networks do not appear to influence

188 dipterocarp seedling growth (Brearley 2003, Saner 2009). These results contrast with

189 that of McGuire (2007) who found that incorporation into an EcM hyphal network was

190 important for seedling growth in a similarly EcM-dominated forest of Guyana.

191 Differences among these forest systems could be related to the differences in tree

192 diversity between the sites, with a monodominant stand in Guyana compared with the

193 high-diversity sites in Southeast Asia. Where there are many EcM parent trees 
belonging to different species, as in Southeast Asia, supporting heterospecific seedlings with carbon compounds may well be selected against.

196

\section{FUNGAL FLORAS AND NEW FUNGAL SPECIES}

The fungal flora of most dipterocarp forests is still very poorly known. Hong (1979) made the first note of putative EcM fungi including Amanita, Boletus, Gyrodon,

Lactarius and Russula species from around dipterocarps at the Forest Research Institute of Malaysia's grounds at Kepong, Peninsular Malaysia. Malaysia is probably one of the best-documented tropical countries in terms of its fungal flora but, even here, it is estimated that only 20 percent of the Peninsula's larger fungi have been collected

204 (Corner, in Lee et al. 1995a).

205 The main site where detailed fruit body surveys have been carried out is Pasoh Forest Reserve in Peninsular Malaysia where Lee Su See, Roy Watling and colleagues have been working since the early 1990s (Lee et al. 2002a, 2003; Watling et al. 1998, 2002, 2006). From these surveys, we know that the most common families found as fruiting bodies are Russulaceae, Boletaceae and Amanitaceae, and 296 species of fruiting body

210 (in 19 predominantly EcM-forming families) have been recorded over a six-yr period (Lee et al. 2003). Around two-thirds of these were undescribed, and over three-quarters of the species were only collected once. Good information on fungal communities is also available from planted dipterocarps at Kepong, Peninsular Malaysia (Lee et al .

214 1996a, Watling \& Lee 1995, 1998) and natural forest at Wanariset Samboja,

215 Kalimantan (Smits 1994, Yasman 1995) and from Corner's early work in Malaysia and 216 Singapore (Corner 1988).

217 The fruiting bodies in the more seasonal dipterocarp forests of Thailand are broadly

218 similar at the family level to those in Malaysia and Indonesia, with addition of Astraeus 
219 (Chalermpongse 1987) that appears to be absent from the more aseasonal forests. There are also minor fungal inventories from Uppangala in the Western Ghats of India (Natarajan et al. 2005) and Sakaerat in Thailand (Chalermpongse 1987) which show similar patterns to the more extensive inventories. López-Quintero et al. (in press) have provided the first records of EcM fruiting bodies associated with the Neotropical dipterocarp Pseudomonotes tropenbosii in Colombia.

\section{DESCRIPTIONS OF DIPTEROCARP-ASSOCIATED ECTOMYCORRHIZAS}

There are very few published descriptions of dipterocarp EcMs and this hinders research for ecologists and mycologists who lack access to molecular sequencing facilities. Becker (1983) and Lee (1988, Lee et al. 1997) described over 25 EcM morphotypes from the roots of Shorea leprosula, and this is currently the most comprehensive set of dipterocarp EcM descriptions that we have. Watling et al. (1995a) described the EcM formed by Pisolithus aurantioscabrosus, Tedersoo et al. (2007a,b) described the EcMs formed by Sordariomycete and Coltriciella species on Vateriopsis seychellarum and Jülich (1985) described the distinctive EcMs of Riessia and Riessiella with abundant cystidia (noted as conidia by Jülich: 1985), with Lee et al. (1997) showing how these particular species differ from many EcMs in lacking a Hartig net. Lee et al. (2010) also described a new Thelephoraceae species (FP160; most probably Tomentella) used in Malaysian inoculation trials.

\section{MOLECULAR STUDIES ON DIPTEROCARP-ASSOCIATED}

\section{ECTOMYCORRHIZAS}

Two of the most comprehensive studies of dipterocarp EcM communities have, ironically, been conducted on rare or outlying species within monospecific genera. 
Moyersoen (2006) found nine EcM species on Pakaraimea dipterocarpacea in

245 Venezuela, and Tedersoo et al. (2007a) found 18 EcM species on Vateriopsis sechellarum in the Seychelles. In Malaysian forests, Sirikantaramas et al. (2003) took root samples from five sites and showed that, belowground, the family producing the

248 greatest number of sequences was the Thelephoraceae with just over half of the

249 sequences. Other important families were Boletaceae, Russulaceae and

250 Sclerodermataceae. Numerically this was similar to the results of Yuwa-Amornpitak et al. (2006) who obtained sequences from root tips from eight sites in Thailand and found, again, Thelephoraceae to provide the greatest number of sequences followed by Russulaceae and Sclerodermataceae. Sirikantaramas et al. (2003) also suggested that Thelephoraceae were often found associated with Shorea species but did not present further evidence to support their case. Currently, the most comprehensive study we have is that of Peay et al. (2010) who examined EcMs in two soil types at Lambir Hills in Sarawak and found that members of the Russulales represented around one-third of the sequences, and the Thelephorales were the fourth most abundant clade (after Boletales and Agaricales). In a dry dipterocarp forest in Thailand, Phosri et al. (in press) found

260 Russulales and Thelephorales to be the most important taxa. In addition, Roy et al. 261 (2009) determined that EcM fungi were associated with three Thai orchid species (two from forests with dipterocarps). These orchids are highly likely to be obtaining carbon subsidies from the associated dipterocarps. Numerically important fungal groups associated with these orchids were Thelephoraceae, Russulaceae, Clavulinaceae and

265 Sebacinales. Tedersoo et al. (2011) have also noted the important EcM species in two 266 African forests containing dipterocarps as non-dominant species. Table 1 summarises 267 the importance of various fungal groups in the studies above with some additional 268 studies also reported. 
270 Tedersoo and Nara (2010) suggest that tropical regions have lower EcM species

271 diversity than temperate regions due to reduced phylogenetic diversity of host trees, and

272 a simpler soil profile, among other reasons. It is difficult, however, to reconcile this

273 suggestion with the very high diversity of fruit bodies collected by Lee et al. (2003) as

274 noted above, especially as belowground diversity has been shown to be higher than

275 aboveground diversity in tropical forest EcM fungal surveys (Henkel et al. in press);

276 clearly more work is needed to resolve this problem.

277

\section{ECTOMYCORRHIZAL COMMUNITY DIVERSITY, DYNAMICS AND}

\section{RESPONSES TO PERTURBATIONS}

280 On Shorea leprosula, Lee et al. (1997) described 24 EcM morphotypes from various sites in Peninsular Malaysia and 36 at Danum Valley in Borneo (Lee et al. 1996b), Ingleby et al. (1998) found a similar number (26) on the roots of Shorea parvifolia as did Moyersoen (2000) on Shorea pachycarpa (29). A much higher richness of $56 \mathrm{EcM}$ morphotypes were found on Hopea nervosa at Danum Valley (Lee et al. 1996b). The number of EcM morphotypes found in two nursery studies (14 and 16 species, Brearley 2003 and Saner et al. 2011 respectively) appears to be lower than the field studies as many late-stage fungi (sensu Deacon et al. 1983) will be absent from nurseries. Individual seedlings may possess up to five different EcM morphotypes with 2-3 being the median number (Lee \& Alexander 1996, Brearley et al. 2003). A succession of EcM

290 fungi was observed on Shorea leprosula seedling root tips during early seedling establishment, and the number of morphotypes increased over the first seven months of seedling growth (Lee \& Alexander 1996). Comparisons between seedling EcM communities will therefore be sensitive to seedling age. 
295 Studies on the population structure of dipterocarp EcMs appear to be limited to a single study. Rivière et al. (2006) examined the spatial distribution of a Russula species in 297 dipterocarp forests dominated by Vateria indica and Dipterocarpus indicus in the

Western Ghats of India. The fruiting bodies were highly aggregated but, using molecular methods, genet size was shown to be vary variable, ranging from a number of single fruiting body genets, to the largest genet containing three fruiting bodies with a maximum distance of $70 \mathrm{~m}$ between them. These data suggest that Russula species can form large genets, in contrast to earlier work that has shown Russula species to form relatively small genets (Redecker et al. 2001, Liang et al. 2004).

HoST SPECIFICITY.- Smits $(1983,1985)$ provided anecdotal evidence suggesting that dipterocarp associated EcMs are highly host specific. Unfortunately, due to the lack of methodology presented in his papers it makes them difficult to evaluate. Furthermore, these results do not agree with those found in temperate regions where many fungi have an intermediate to broad host range, certainly at the host genus taxonomic level or above (Molina et al. 1992). Current evidence suggests that host specificity of

311 dipterocarp EcMs is not as common as claimed by Smits $(1983,1985)$ with weak

312 evidence for host specificity provided by Ingleby et al. (2000) who showed that

313 seedlings of Dipterocarpus alatus grown in soil from a Hopea odorata plantation in

314 Vietnam formed only one EcM morphotype, and this was different to the four

315 morphotypes on Hopea odorata seedlings. Becker (1983) described ten EcM

316 morphotypes from Shorea leprosula and Shorea maxwelliana at Pasoh of which two

317 were shared between the two hosts. Similarly, Berriman (1986) showed that three out of

31811 morphotypes were shared between three Shorea seedling species (Shorea leprosula, 
319 Shorea lepidota and Shorea macroptera) and seven were found on only one of the

320

321

322

323

324

326

327

328

330

331

332

333

334

335

336

337

338

339

340

341

342

343

species. In nursery-grown dipterocarp seedlings, seven of 14 EcM morphotypes found were present on the roots of at least three of the four host seedling species of

Dryobalanops lanceolata, Hopea nervosa, Parashorea tomentella and Shorea leprosula (Brearley et al. 2003, 2007). Lee et al. (1996b) recorded 61 EcM morphotypes on the roots of seedlings of Hopea nervosa and Shorea leprosula in forests at Danum Valley in Sabah, of which 31 were found on both species, 25 were found on Hopea nervosa only, and only five were found exclusively on Shorea leprosula. Examination of associations of fruit bodies with planted dipterocarp species suggests that Russula virescens is putatively associated with at least ten dipterocarp species and Boletus aureomycelinus with 21 species (Watling and Lee 1998). All of the above evidence suggests a modest amount of host specificity although the degree to which this simply represents random sampling of rare species can only be ascertained with more extensive sampling. At a higher taxonomic level, two dipterocarp-associated EcM fungi (Pisolithus aurantioscabrosus and Tomentella FP160) have also been shown to form EcMs on Acacia mangium although it is not yet known if these are functionally important (Lee \& Patahayah 2003). Of the 18 species of EcM fungi on Vateriopsis seychellarum, three were shared with Intsia bijuga, and another three were shared with introduced Eucalyptus robusta (Tedersoo et al. 2007a). As a long-isolated island endemic (occurring only on a single island of the Seychelles) and an evolutionary basal lineage, $V$. seychellarum might not, however, be very representative of the Asian dipterocarps in this respect.

REPONSES TO NUTRIENT AVAILABILITY.- Many studies show that mycorrhizal colonization decreases under conditions of higher soil, and especially P, fertility (Jones 
et al. 1990, Baum \& Makeschin 2000, Treseder 2004) but the results from dipterocarps

345 are variable. Turner et al. (1993) found that NPK fertilization increased percentage EcM colonization on Shorea macroptera seedlings, and the correlation between percentage

347 EcM and seedling biomass was stronger if the unfertilised seedlings were analysed 348 alone. Similarly, Lee and Lim (1989) found that only seedlings from a less fertile site 349 had a correlation between percentage EcM colonization and foliar P concentrations.

350 Irino et al. (2004) showed that addition of a NPK fertilizer increased EcM colonization on pot-grown Dryobalanops lanceolata, although colonization was very low (8\%) in the control seedlings. In contrast, addition of $\mathrm{P}$ in various studies had no effect on $\% \mathrm{EcM}$ on Shorea leprosula (Suhardi 2000), two species of Dryobalanops in two contrasting soil types (Palmiotto et al. 2004), or on Hopea nervosa and Shorea leprosula (Brearley et al. 2007). However, the latter study did find species-specific responses to increased nutrient availability, most notably for Riessiella sp. that increased following $\mathrm{P}$ fertilization. This suggests that Riessiella might not be a fully mutualistic fungus (Brearley et al. 2007); further evidence for this hypothesis is that it also does not possess a Hartig Net (Lee et al. 1997), which is the site of nutrient transfer between the fungus and the plant. The lack of a consistent response to $\mathrm{P}$ fertilization in these studies suggests that EcMs are important even under conditions of higher nutrient supply as colonization rarely declines, suggesting they are still involved in assisting in seedling nutrient uptake.

365 When an organic nutrient source of mixed leaf litter was added to the soil medium there was no change in percentage EcM colonization for three dipterocarp seedling species

367 (Brearley et al. 2003). In contrast, the diversity of EcM species on seedling's roots was 368 reduced with litter addition; this was partly driven by the reduction in colonization by 
Cenococcum geophilum. Addition of Imperata cylindrica (alang-alang) litter reduced

370

371

372

373

374

375

376

377

378

379

380

381

382

383

384

385

386

387

388

percentage EcM colonization in Shorea bracteolata (Suhardi et al. 1993), perhaps due to its allelopathic nature (Brook 1989).

RESPONSES TO SOIL TYPES .- The EcM community on the roots of nursery-grown

Dryobalanops lanceolata is considerably different when seedlings are grown on ultramafic (with high levels of metals such as $\mathrm{Fe}, \mathrm{Mg}, \mathrm{Ni}, \mathrm{Co}$ and $\mathrm{Cr}$ ) as compared to a more typical non-ultramafic ultisol soil (Brearley 2006), notably in that Cenococcum geophilum and Inocybe spp. decreased, and Boletales sp. increased in ultramafic soils, and EcM diversity was also higher. Similarly, Iwamoto and Kitayama (2002) found eleven EcM morphotypes in ultramafic soil compared to only two in a sedimentary soil from dipterocarp-dominated forests at around $700 \mathrm{~m}$ asl on Mount Kinabalu in Borneo.

Sandy soils at Lambir Hills, Sarawak, had a greater number of EcM species than clay soils (65 vs. 41), perhaps due to more differentiated soil horizons of the sandy soils or the lower nutrient concentrations, allowing coexistence of a greater number of species (Peay et al. 2010). Such results might also, however, be due to different tree compositions on the different soil types. There was also evidence of more phylogenetic clustering of EcM species on the clay soil, giving rise to a community more dominated by Russulales and Thelephorales and lacking Cortinariaceae. Seedlings of Dryobalanops lanceolata (but not D. aromatica) at Lambir Hills had more than double the biomass of EcM when grown on their preferred soil type (clay and sandy soils respectively; Palmiotto et al. 2004) 
REPONSES TO IRRADIANCE.- Studies examining changes in EcM colonization in response to differing irradiances are somewhat contrasting, most likely this is due to changes in carbohydrate flow from plant to fungus but will also be due to the differing environmental conditions associated with higher irradiance, such as higher soil temperatures. High light conditions (e.g. in forest gaps) appear to increase EcM colonization (Becker 1983; Ingleby et al. 1998). EcM colonization on five Sri Lankan Shorea species was also greatest under higher irradiances, often under full sunlight, even though this did not correspond to conditions most suited to seedling growth of these species (Tennakoon et al. 2005). In contrast, Yasman (1995) found the greatest EcM colonization under irradiances where seedling growth was also most rapid, while other studies have shown no clear difference among different light treatments of EcM abundance on seedlings of two contrasting species, Shorea leprosula and Hopea nervosa (Brearley et al. 2007). When considering diversity of EcMs under differing conditions we may also need to examine the size of the root system and the number of root tips present, as, analogous to a species-area effect, larger root systems with more root tips may well host more EcM species (see Taylor 2002).

\section{RESPONSES TO BURNING.- Tata et al. (2003) did not find any EcM fruit bodies in} forests burnt in 1998 in East Kalimantan (examined in 2000) and, using two dipterocarp seedling species as bait plants, she found there was no difference in the proportion of seedlings with EcM (although values for both species were low at around 5\%) among seedlings grown in the burnt and unburnt forest soils. In contrast, Akema et al. (2009) found that in a severely burnt site (examined in 2002) there were no EcM root tips in the soil, although there were some fruiting bodies of typically early stage fungi (Laccaria vinaceoavellana). In the moderately burnt site, four EcM morphotypes were found, with 
418 dominance by one species, compared to a much more even EcM community in

419 undisturbed forest where eight morphotypes were found. There was also an indication

420 that EcMs in the unburnt forest were concentrated in the surface soil layer, but were

421 more evenly distributed in the soil in the moderately fire-affected site. Several reasons

422 for severe reduction in EcMs in burnt forests include changed microclimate, changes in

423 the input of leaf litter, volatilization of organically bound nutrients, the death of host

424 trees, and possible sterilization of upper layers of the soil by the fires (Certini 2005)

425

426

REPONSES TO LOGGING DISTURBANCE.- - Initial fruit body data from Pasoh showed

slightly more EcM species in logged (98) than unlogged (75) forest (largely due to more

Russula species), although only around 10 percent of species were shared by both forest types (Watling et al. 1998). Additional data revealed that logged forests contained only 32 percent of the fungal flora of the forest reserve as a whole (Watling et al. 2002), although this number is difficult to put into context given the differences in area and sampling effort between the logged and unlogged forests. Lee et al. (1996b) found no difference in percentage EcM on Hopea nervosa and Shorea leprosula in recently

434 logged (up to three yr previously) and unlogged plots at Danum Valley, Sabah, and the number of EcM morphotypes on the roots of the seedlings showed no consistent patterns across the three paired sites studied. Of the 61 EcM morphotypes, 30 were exclusive to unlogged forest whereas 16 were restricted to logged forest; furthermore, of 29 EcM morphotypes which were found only in one of the sixteen plots, around three-

439 quarters of these were found in unlogged forest only, suggesting that logging may have 440 more of a negative impact on uncommon EcM morphotypes. Ingleby et al. (1998) 441 examined EcMs on Shorea parvifolia nine months after hand logging and found an increased diversity of EcM morphotypes under the logged, higher irradiance conditions. 
443 However, in this study it is difficult to disentangle the effects of logging from increased

444 light levels created by logging disturbance. The immediate impacts of logging on the

445 diversity and functioning of the EcM communities has not yet been assessed.

446

\section{COLONIZATION BY OTHER (SYMBIOTIC) FUNGAL STRUCTURES}

448 There are reports of some dipterocarps also forming arbuscular mycorrhiza (AM)

449 associations (Shamsudin 1979, Chalermpongse 1987, Ibrahim et al. 1995, Dhungana et

450 al. 1996, Shi et al. 2002, 2007; Tawaraya et al. 2003) and an important question is how

451

common is dual colonization, and are interactions among colonisers beneficial to the

host plants, as seen by Chen et al. (2000) for eucalypts? The only data on dual

colonization did not find a difference in the relative growth rate of Hopea odorata

seedlings with EcM alone (38 out of 54 seedlings) or dual EcM/AM colonization (16

455

out of 54 seedlings) (Ibrahim et al. 1995). Ectendomycorrhizal colonization has also

been reported in Shorea parvifolia (Louis 1988) and other dipterocarps (Chalermpongse 1987, Tupas and Sajise 1976). All of the above information suggests that there could be a considerable diversity of mycorrhizal morphologies in the Dipterocarpaceae, and additional morphological information on mycorrhizal symbioses is needed.

460

461

\section{FUTURE WORK}

462

Increased knowledge of dipterocarp-associated EcM fungal community structure is

463 being facilitated by extensive and long-term fruiting body surveys as well as molecular

464 analyses of belowground EcM communities. Nursery and field based studies are improving understanding of growth and nutrition relations of EcM dipterocarp seedlings (Brearley 2011). The following areas for future research on dipterocarp-associated EcM fungi and plant-fungal ecosystem interactions are suggested: 
469 (1) Bring more EcM fungi into culture and test them for functional symbiotic

470 capabilities. Fungi that appear to promote plant performance should be further

471 investigated in field studies where the ecological importance of EcM for dipterocarp

472 growth and survival is most important although currently equivocal.

473

474 (2) It is important to determine the roles that fungi might be playing in ecosystem 475 nutrient cycling processes. How do they influence leaf litter decomposition and the 476 subsequent release of nutrients? This might be achieved by analyses of extracellular 477 enzyme activities. Do EcMs influence ecosystem processes? A nitrogen isotopic budget 478 of ecosystem compartments might shed some light on the importance of EcM fungi in 479 nitrogen-cycling processes (see Hobbie \& Hobbie 2008).

480

481 (3) Community studies on EcM root tips and fruiting bodies are needed, as are studies 482 of community dynamics in response to land-use change or other current global changes. 483 Our understanding of EcM responses to logging remains rudimentary, and it is not clear 484 which species or groups of species are more or less affected by disturbances. Although 485 some studies have suggested that temperate and tropical EcM communities have similar diversity, tropical studies are mostly short term and have not examined, for example, 487 differentiation by depth or seasonal changes. Linking fungal diversity with ecosystem 488 processes in tropical forests, and how such relationships are affected by disturbances is 489 another area of considerable research importance..

491 (4) Taxonomic capacity for fungal studies in the appropriate geographical regions needs 492 to be improved, for both traditional taxonomy as well as molecular taxonomy. Herbaria 
493 provide a valuable repository of sequence diversity (e.g., Brock et al. 2008) and

494 sequences from identified fungal fruit body specimens would allow us to relate

495 belowground to aboveground fungal diversity in a more meaningful way.

496

497 (5) We should be determining the ecophysiological requirements of selected

498 functionally important tropical EcM isolates. Other than those studies on species of

499 interest for inoculation schemes (Patahayah et al. 2003, Brearley et al. 2005) there is

500 minimal knowledge on the ecophysiology of tropical EcM fungi. For example, what are

501 their temperature and nutrient requirements? Can they access organic nutrients, as has

502 been shown in temperate regions?

503

504 (6) And finally, what is the morphological diversity of mycorrhizal types? Is dual

505 mycorrhizal colonization common and functionally important? If so, what are the

506 developmental, physiological and environmental factors in controlling potential dual

507 colonization?

508

509 ACKNOWLEDGMENTS

510 I thank the British Ecological Society for funding my Ph.D. research on dipterocarp

511 ectomycorrhizas in Sabah, Malaysia (1999-2003) and Dr. Lee Su See and her staff for

512 collaboration and support of my current research in Peninsular Malaysia (2009

513 onwards). David Burslem, Jaboury Ghazoul, Bernard Moyersoen and two anonymous

514 reviewers provided helpful comments that improved the manuscript.

515

516

517 


\section{LITERATURE CITED}

519 Akema, T., I. Nurhiftisni, Suciatmin, ANd H. Simbolon. 2009. The impact of the

520

521

522

523

524

525

526

527

528

529

530

531

532

533

534

535

536

537

538

539

540

541

542

1998 forest fire on ectomycorrhizae of dipterocarp trees and their recovery in tropical forests of East Kalimantan, Indonesia. JARQ 43: 137-143.

Albrecht, C., T. Burgess, B. Dell, AND F. F. Lapeyrie. 1994. Chitinase and peroxidase activities are induced in eucalyptus roots according to aggressiveness of Australian ectomycorrhizal strains of Pisolithus sp. New Phytol. 127: 217-222.

AleXANDER, I. J. 2006. Ectomycorrhizas - out of Africa? New Phytol. 172: 589-591.

AleXANDER, I. J., AND P. HöGBERG. 1986. Ectomycorrhizas of tropical angiospermous trees. New Phytol. 102: 541-549.

AleXANDER, I. J., A. NoRANi, AND S. S. LEE. 1992. The role of mycorrhizas in the regeneration of some Malaysian forest trees. In A. G. Marshall and M. D. Swaine (Eds.). Tropical Rain Forest: Disturbance and Recovery, pp. 357-367. The Royal Society, London, UK.

Baillie, I. C., P. S. Ashton, S. P. Chin, S. J. Davies, P. A. Palmiotto, S. E. Russo, AND S. TAN. 2006. Spatial association of humus, nutrients and soil in mixed dipterocarp forest at Lambir, Sarawak, Malaysian Borneo. J. Trop. Ecol. 22: 543 553.

BAUM, C., AND F. MAKESCHIN. 2000. Effects of nitrogen and phosphorus fertilization on mycorrhizal formation of two poplar clones (Populus trichocarpa and P. tremulax tremuloides). J. Plant Nutr. Soil Sci. 163: 491-497.

BECKER, P. 1983. Ectomycorrhizas on Shorea (Dipterocarpaceae) seedlings in a lowland Malaysian rainforest. Malay. For. 46: 146-170.

BÉREAU, M., M. GAZEL, AND J. GARBAYE. 1997. Les symbioses mycorhiziennes des arbres de la forêt tropicale humide de Guyana française. Can. J. Bot. 75: 711-716. 
Beimforde, C., N. SchäFER, H. Dörfelt, P. C. NAscimbene, H. Singh, J. HeInRIChS,

544 J. REITNER, R. S. RANA, AND A. R. SCHMIDT. 2011. Ectomycorrhizas from a Lower $545 \quad$ Eocene angiosperm forest. New Phytol. 192 : 988-996.

546 BerRimAn, C. P. 1986. Mycorrhizas of Shorea (Dipterocarpaceae) in Relation to Host

547 Specificity and Soil Phosphorus Status. B.Sc. Dissertation, University of Aberdeen, $548 \quad$ UK.

549 BREARLEY, F. Q. 2003. The Role of Ectomycorrhizas in the Regeneration of

550 Dipterocarp Seedlings. Ph.D. Dissertation, University of Sheffield, UK.

551 BREARLEY, F. Q. 2006. Differences in the growth and ectomycorrhizal community of

552 Dryobalanops lanceolata (Dipterocarpaceae) seedlings grown in ultramafic and

553 non-ultramafic soils. Soil Biol. Biochem. 38: 3407-3410.

554 BREARLEY, F. Q. 2011. The importance of ectomycorrhizas for the growth of

555 dipterocarps and the efficacy of ectomycorrhizal inoculation schemes. In M. Rai and

556 A. Varma (Eds.). Diversity and Biotechnology of Ectomycorrhizae, pp. 3-17.

557 Springer-Verlag, Berlin, Germany.

558 Brearley, F. Q., M. C. Press, AND J. D. Scholes. 2003. Nutrients obtained from leaf 559 litter can improve the growth of dipterocarp seedlings. New Phytol. 160: 101-110.

560 Brearley, F. Q., S. Prajadinata, P. S. Kidd, J. Proctor, and Suriantata 2004.

561 Structure and floristics of an old secondary rain forest in Central Kalimantan,

562 Indonesia, and a comparison with adjacent primary forest. For. Ecol. Manage. 195:

$563 \quad 385-397$.

564 Brearley, F. Q., J. D. SchOles, AND S. S. LEE. 2005. Nitrogen nutrition and isotopic 565 discrimination in tropical ectomycorrhizal fungi. Res. Microbiol. 156: 184-190. 
Brearley, F. Q., J. D. Scholes, M. C. Press, And G. Palfner. 2007. How does light and phosphorus fertilisation affect the growth and ectomycorrhizal community of two contrasting dipterocarp species? Plant Ecol. 192: 237-249.

569

Brock, P. M., H. DöRING, AND M. I. BiDARTONDO. 2008. How to know unknown fungi: the role of a herbarium. New Phytol. 181: 719-724.

BRoOK, R. M. 1989. Review of literature on Imperata cylindrica (L.) Raueschel with particular reference to south east Asia. Trop. Pest Manage. 35: 12-25.

CERTINI, G. 2005. Effects of fires on properties of forest soils: a review. Oecologia, 143:

574 $1-10$.

CHALERMPONGSE, A. 1987. Mycorrhizal survey of dry-deciduous and semi-evergreen dipterocarp forest ecosystems in Thailand. In A. J. C. H. Kostermans (Ed.). Proceedings of the Third Round Table Conference on Dipterocarps, pp.81-103.

ChAnG, Y. S., F. F. LAPEYRIE, AND S. S. LEE. 1994. The survival and competitiveness of on Dipterocarps, pp. 165-169. Forest Research Institute of Malaysia, Kepong, Malaysia.

Chang, Y. S., S. S. LeE, F. F. LAPEYRIE, AND S. M. YAZID. 1995. The competitiveness of two strains of Pisolithus tinctorius on seedlings of three species of dipterocarps under nursery and field conditions: preliminary results. In R. Wickneswari, A. Z. Yahya, A. H. M. Shariff, D. Haji Ahmad, K. C. Khoo, K. Suzuki, S. Sakurai and K. Ishii (Eds.). Proceedings of the International Workshop of BIO-REFOR, Kangar, 1994, pp. 208-212. BIO-REFOR, IUFRO-SPDC, Tokyo, Japan \& Forest Research Institute of Malaysia, Kepong, Malaysia. 
591

592

593

594

595

596

597

598

599

600

601

602

603

604

605

606

607

608

609

610

611

612

613

614

615

Chen, Y. L., M. C. Brundrett, AND B. Dell. 2000. Effects of ectomycorrhizas and vesicular-arbuscular mycorrhizas, alone or in competition, on root colonization and growth of Eucalyptus globulus and E. urophylla. New Phytol. 146: 545-556.

ConNell, J. H., AND M. D. LowMAN. 1989. Low-diversity tropical rain forests: some possible mechanisms for their existence. Am. Nat. 134: 88-119.

Corner, E. J. H. 1972. Boletus in Malaysia. Government Printing Office, Singapore.

CORNER, E. J. H. 1988. Higher fungi. In: Earl of Cranbrook (Ed.). Key Environments: Malaysia, pp. 88-101. Pergamon Press, Oxford, UK.

DARUSMAN, L. K. 1998. Kinetics of root chitinase during the association process between Shorea selanica and mycorrhiza of Scleroderma columnare. Hayati 5: 9597.

Dayanandan, S., P. S. Ashton, S. M. Williams, And R. B. Primack. 1999. Phylogeny of the tropical tree family Dipterocarpaceae based on nucleotide sequences of the chloroplast $r b c L$ gene. Am. J. Bot. 86: 1182- 1190.

DE ALWIS, D. P., AND K. ABEYNAYAKE. 1980. A survey of mycorrhiza in some forest trees in Sri Lanka. In P. Mikola (Ed.). Tropical Mycorrhiza Research, pp. 146153. Clarendon Press, Oxford, UK.

DE Alwis, D. P., AND K. ABEYNAYAKE. 1988. Aseptic synthesis of mycorrhizae of Dipterocarpus zeylandicus. In F. S. P. Ng (Ed.). Trees and Mycorrhiza: Proceedings of the Asian Seminar pp. 215-226. Forest Research Institute of Malaysia, Kepong, Malaysia.

DE Voogd, C. N. A. 1933. Cultuurproeven met Shorea platyclados v. Sl. in Redjang en Lebong. Tectona 26: 703-713.

DeACon, J. W., S. D. Donaldson, AND F. T. LASt. 1983. Sequences and interactions of mycorrhizal fungi on birch. Plant Soil 71: 257-262. 
Dhungana, H. N., D. DutTa, G. S. SARMA, AND P. HAZARIKA. 1996. Occurrence of vesicular-arbuscular mycorrhizae in seedlings of some forest tree species. J. Trop. For. 12: 156-158.

619

Ducousso, M., G. Béna, C. Bourgeois, B. Buyck, G. Eyssartier, M. Vincelette, R. RabeVohitra, L. RANDrihasipara, B. Dreyfus, AND Y. Prin. 2004. The last common ancestor of Sarcolaenaceae and Asian dipterocarp trees was ectomycorrhizal before the India-Madagascar separation, about 88 million years ago. Mol. Ecol. 13: 231-236.

624

Eyssartier, G., D. Stubbe, R. WALleyn, AND A. VerbeKen. 2009. New records of Cantharellus (Basidiomycota, Cantharellaceae) from Malaysian dipterocarp rainforest. Fungal Div. 36: 57-67.

Hadi, S., AND E. SAntoso. 1988. Effect of Russula spp., Scleroderma sp. and Boletus 628 sp. on the mycorrhizal development and growth of five dipterocarp species. In M. Mohinder Singh (Ed.). Agricultural and Biological Research Priorities in Asia, Proceedings of the IFS Symposium of Science Asia 87, pp. 183-185. International Foundation for Science \& Malaysian Scientific Association, Kuala Lumpur, Malaysia.

HADI, S., AND E. SANTOSO. 1989. Accumulation of macronutrients by five dipterocarp 634 species inoculated with different species of mycorrhizal fungi. In A. Mahadevan, N. on Botany, University of Madras, India.

HAWKSWORTH, D. L. 1993. The tropical fungal biota: census, pertinence, prophylaxis, 
641 HeNKEL, T. W. 2003. Monodominance in the ectomycorrhizal Dicymbe corymbosa

642 (Caesalpiniaceae) from Guyana. J. Trop. Ecol. 19: 417-437.

643 Henkel, T. W., M. C. Aime, M. M. L. Chin, S. L. Miller, R. Vilgalys and M. E.

644 SMITH. In press. Ectomycorrhizal fungal sporocarp diversity and discovery of new

645 taxa in Dicymbe monodominant forests of the Guiana Shield. Biodivers. Conserv.

646 HobBIE, E. A., AND J. E. HobBIE. 2008. Natural abundance of ${ }^{15} \mathrm{~N}$ in nitrogen-limited

647 forests and tundra can estimate nitrogen cycling through mycorrhizal fungi: a

648 review. Ecosystems 11: 815-830.

649 Hong, L. T. 1979. A note on dipterocarp mycorrhizal fungi. Malay. For. 42: 280-283.

650 IBRAHIM, Z., M. N. MAHAT, AND S. S. LEE. 1995. Response of Hopea odorata seedlings

651 to biological soil conditioners. In R. Wickneswari, A. Z. Yahya, A. H. M. Shariff,

652 D. Haji Ahmad, K. C. Khoo, K. Suzuki, S. Sakurai and K. Ishii (Eds.). Proceedings

653 of the International Workshop of BIO-REFOR, Kangar, 1994, pp.179-182. BIO-

654 REFOR, IUFRO-SPDC, Tokyo, Japan \& Forest Research Institute of Malaysia,

$655 \quad$ Kepong, Malaysia.

656 IngLeBY, K. 1999. Inocybe avellana Horak + Shorea leprosula Miq. In R. Agerer, R. M.

657 Danielson, S. Egli, K. Ingleby, D. Luoma and R. Treu (Eds.). Descriptions of

658 Ectomycorrhizae, Volume 4, pp. 55-60. Einhorn-Verlag, Schwäbisch Gmünd,

659 Germany.

660 Ingleby, K., R. C. Munro, M. Noor, P. A. Mason, And M. J. Clearwater. 1998.

661 Ectomycorrhizal populations and growth of Shorea parvifolia (Dipterocarpaceae)

662 seedlings regenerating under three different forest canopies following logging. For.

663 Ecol. Manage. 111: 171-179. 
Ingleby, K., L. T. T. Thuy, N. T. Phong, And P. A. MASON. 2000. Ectomycorrhizal inoculum potential of soils from forest restoration sites in south Vietnam. J. Trop. For. Sci. 12: 418-422.

Irino, K. O., Y. IbA, S. Ishizuka, T. KenZO, S. Ripot, J. J. KendaWAng, N. MiYAShitA, K. NARA, T. Hogetsu, I. NinOmiya, K. IwASAKI, AND K. SAKURAi. 2004. Effects of controlled-release fertilizer on growth and ectomycorrhizal colonization of potgrown seedlings of the dipterocarp Dryobalanops lanceolata in a tropical nursery. Soil Sci. Plant Nutr. 50: 747-753.

IWAMOTO, K., AND K. KitAYAMA. 2002. Abundances of ectomycorrhizas on the slopes of Mount Kinabalu, Sabah, Malaysian Borneo. Sabah Park. Nat. J. 5: 239-255.

Jones, M. D., D. M. Durall, AND P. B. TINKER. 1990. Phosphorus relationships and production of extramatrical hyphae by two types of willow ectomycorrhizas at different soil phosphorus levels. New Phytol. 115: 259-267

JÜLICH, W. 1985. Fungi associated with Dipterocarpaceae in Southeast Asia. 1. The genera Riessia and Riessiella. Int. J. Mycol. Lichenol. 2: 123-140.

KETTLE, C. J. 2010. Ecological considerations for using dipterocarps for restoration of lowland rainforest in Southeast Asia. Biodivers. Conserv. 19: 1137-1151.

LEE, S. S. 1998. Root symbiosis and nutrition. In S. Appanah and J. M. Turnbull (Eds.). A Review of Dipterocarps: Taxonomy, Ecology and Silviculture, pp. 99-114. Centre for International Forestry Research, Bogor, Indonesia.

LEE, S. S. 2005. Macrofungal diversity in Peninsular Malaysia focusing on the ectomycorrhizal fungi. Clusiana 44: 57-66.

LEE, S. S., AND I. J. ALEXANDER. 1994. The response of seedlings of two dipterocarp species to nutrient additions and ectomycorrhizal infection. Plant Soil 163: 299306. 
LEE, S. S., AND I. J. ALEXANDER. 1996. The dynamics of ectomycorrhizal infection of Shorea leprosula seedlings in Malaysian rain forests. New Phytol. 132: 297-305.

LEE, S. S., AND K. L. LIM. 1989. Mycorrhizal infection and foliar phosphorus content of seedlings of three dipterocarp species grown in selectively logged forest and a forest plantation. Plant Soil, 117: 237-241.

LEE, S. S., AND M. PATAhayAh. 2003. Host specificity of dipterocarp ectomycorrhizal fungi. In H. Aminah, S. Ani, H. C. Sim and B. Krishnapillay (Eds.). Proceedings of the Seventh Round-Table Conference on Dipterocarps. 7-10 October 2002, pp. 214-217. Asia Pacific Association of Forestry Research Institutions, Kuala Lumpur, Malaysia.

LEE, S. S., H. BeSL, AND S. UJANG. 1995a. Some fungi of the Sungai Halong and surrounding areas, Temengor Forest Reserve, Hulu Perak, Malaysia. Malay. Nat. J. 48: 147-155.

LEE, S. S., F. F. LAPEYRIE AND S. M. YAZID. 1995b. Techniques for controlled ectomycorrhizal inoculation of dipterocarp seedlings and cuttings. In Supriyanto and J. T. Kartana (Eds.). Proceedings of the Second Symposium on Biology and Biotechnology of Mycorrhizae and Third Asian Conference on Mycorrhizae (ACOM III), BIOTROP Special Publication 56, pp.217-221. SEAMEO BIOTROP, Bogor, Indonesia.

LEE, S. S., R. WATLing, AND E. TuRnBull. 1996a. Ectomycorrhizal fungi as possible bio-indicators in forest management. In N. Hussein, P. S. Bacon and K. C. Khoo (Eds.). Forestry and Forest Products Research: Proceedings of the Third Conference, Volume 1, pp. 63-68. Forest Research Institute of Malaysia, Kepong, Malaysia. 
Lee, S. S., I. J. Alexander, P. H. Moura-Costa, And S. W. YaP. 1996b. Mycorrhizal

714

715

716

717

718

719

720

721

722

723

724

725

726

727

728

729

730

731

732

733

734

735

736 infection of dipterocarp seedlings in logged and undisturbed forests. In $\mathrm{S}$. Appanah and K. C. Khoo (Eds.). Proceedings of the Fifth Round Table Conference on Dipterocarps, pp. 157-164. Forest Research Institute of Malaysia, Kepong, Malaysia.

LeE, S. S., I. J. AleXANDER, AND R. WATLING. 1997. Ectomycorrhizas and putative ectomycorrhizal fungi of Shorea leprosula Miq. (Dipterocarpaceae). Mycorrhiza 7: $63-81$

LEE, S. S., R. WATLING, AND Y. NORAINI SIKIN. 2002a. Ectomycorrhizal basidiomata fruiting in lowland rain forests of peninsular Malaysia. Bois Fôr. Trop. 274(4): $33-43$

Lee, S. S., M. Patahayah, And F. F. LAPEyrie. 2002b. Exotic vs. indigenous ectomycorrhizal fungi for inoculation of dipterocarps. In K. Ishii, M. Matsumori and K. Suzuki (Eds.). BIO-REFOR: Proceedings of Tokyo-Workshop, pp. 84-87. BIO-REFOR, IUFRO-SPDC, Tokyo, Japan.

LEE, S. S., R. WATLING, AND E. TURNBULL. 2003. Diversity of putative ectomycorrhizal fungi in Pasoh Forest Reserve. In T. Okuda, N. Manokaran, Y. Matsumoto, K. Niiyama, S. C. Thomas and P. S. Ashton (Eds.). Pasoh: Ecology of a Lowland Rain Forest in Southeast Asia, pp. 149-159. Springer-Verlag, Tokyo, Japan.

Lee, S. S., M. Patahayah, W. S. Chong, And F. F. Lapeyrie. 2008. Successful ectomycorrhizal inoculation of two dipterocarp species with a locally isolated fungus in Peninsular Malaysia. J. Trop. For. Sci. 20: 237-247.

LEe, S. S., B. K. Thi, AND M. PATAhayAH. 2010. An ectomycorrhizal Thelephoroid fungus of Malaysian dipterocarp seedlings. J. Trop. For. Sci. 22: 355-363. 
LePage, B. A., R. S. Currah, R. A. Stockey, and G. W. Rothwell. 1997. Fossil ectomycorrhizae from the middle Eocene. Am. J. Bot., 84: 410-412.

739

740

741

742

743

744

745

746

747

748

749

750

751

752

753

754

755

756

757

758

759

760
LiANG, Y., L.-D. GUO, AND K.-P. MA. 2004. Genetic structure of a population of the ectomycorrhizal fungus Russula vinosa in subtropical woodlands in southwest China. Mycorrhiza 14: 235-240.

LóPez-Quintero, C. A., G. StraAtsma, A. E. Franco-Molano, And T. Boekhout. in press. Macrofungal diversity in Colombian Amazon forests varies with regimes of disturbance. Biodivers. Conserv.

LOUIS, I. 1988. Ecto- and ectendomycorrhizae in the tropical dipterocarp, Shorea parvifolia. Mycologia 80: 845-849.

LOUIS, I., AND E. SCOTT. 1987. In vitro synthesis of mycorrhiza in root organ cultures of a tropical dipterocarp species. Trans. Br. Mycol. Soc. 88: 565-568.

MCGUIRE, K. L. 2007. The common ectomycorrhizal net may maintain monodominance in a tropical rain forest. Ecology 88: 567-574.

McGuire, K. L., T. W. Henkel, I. Granzow de la Cerda, G. Villa, F. Edmund, AND C. ANDREW. 2008. Dual mycorrhizal colonization of forest-dominating tropical trees and the mycorrhizal status of non-dominant tree and liana species. Mycorrhiza 18: 217-222.

Molina, R., H. B. MASsicotTe, AND J. M. TRAPPE. 1992. Specificity phenomena in mycorrhizal symbioses: community ecological consequences and practical applications. In M. F. Allen (Ed.). Mycorrhizal Functioning: an Integrative PlantFungal Process, pp. 357-423. Chapman \& Hall, New York, USA.

MOYERSOEN, B. 1993. Ectomicorrizas y micorrizas vesículares-arbusculares en Caatinga Amazónica. Scientia Guaianæ 3, Caracas, Venezuala. 
761

762

763

764

765

766

767

768

769

770

771

772

773

774

775

776

777

778

779

780

781

782

783

784

MOYERSOEN, B. 2000. Diversity of ectomycorrhizal fungi associated with four species and two genera of Dipterocarpaceae in a field and bioessay experiment in Brunei Darussalam. In Anon. (Ed.). Tropical Mycology 2000 Abstracts, p. 25. British Mycological Society, London, UK.

Moyersoen, B. 2006. Pakaraimaea dipterocarpacea is ectomycorrhizal, indicating an ancient Gondwanaland origin for the ectomycorrhizal habit in Dipterocarpaceae. New Phytol. 172: 753-762.

NAtArajan, K., G. Senthilarasu, V. Kumaresan, AND T. Rivière. 2005. Diversity in ectomycorrhizal fungi of a dipterocarp forest in Western Ghats. Curr. Sci. 88: 1893-1895.

Newbery, D. McC., I. J. AleXander, D. W. Thomas, And J. S. Gartlan. 1988. Ectomycorrhizal rainforest legumes and soil phosphorus in Korup National Park, Cameroon. New Phytol. 109: 433-450.

Newman, M. F., P. F. Burgess, And T. C. Whitmore. 1996. Manuals of Dipterocarps for Foresters: Borneo Island Light Hardwoods. Royal Botanic Garden, Edinburgh, UK.

Newman, M. F., P. F. Burgess, And T. C. Whitmore. 1998. Manuals of Dipterocarps for Foresters: Borneo Island Medium and Heavy Hardwoods. Royal Botanic Garden, Edinburgh, UK.

Newsham, K. K., A. H. Fitter, And A. R. WAtKinson. 1995. Multi-functionality and biodiversity in arbuscular mycorrhizas. TREE 10: 407-411.

Palmiotto, P. A., S. J. Davies, K. A. Vogt, P. M. S. Ashton, D. J. Vogt, And P. S. ASHTON. 2004. Soil-related habitat specialization in dipterocarp rain forest tree species in Borneo. J. Ecol. 92: 609-623. 
PAOLI, G. D., L. M. CURRAN, AND D. R. ZAK. 2006. Soil nutrients and beta diversity in the Bornean Dipterocarpaceae: evidence for niche partitioning by tropical rain forest trees. J. Ecol., 94: 157-170.

788

789

790

791

792

793

794

795

796

797

798

799

800

801

802

803

804

805

806

807

808

809

PATAhayah, M., P. C. CynThiA, AND S. S. LEe. 2003. Optimizing growth conditions for ectomycorrhizal inoculum production of the Malaysian strain of Pisolithus tinctorius. In A. H. Mohamed, I. H. Parlan, S. Ibrahim, S. Y. M. Yussof, H. F. Lim, M. A. M. Idris, A. R. A. Ghani, S. Ujang and K. A. Hamzah (Eds.). Tropical Forestry Research in the New Millennium: Meeting Demands and Challenges. Proceedings of the International Conference on Forestry and Forest Products Research (CFFPR 2001), pp. 551-552. Asia Pacific Association of Forestry Research Institutions \& Forest Research Institute of Malaysia, Kuala Lumpur, Malaysia.

Peay, K. G., P. G. Kennedy, S. J. Davies, S. Tan, and T. D. Bruns. 2010. Potential link between plant and fungal distributions in a dipterocarp rainforest: community and phylogenetic structure of tropical ectomycorrhizal fungi across a plant and soil ecotone. New Phytol. 185: 529-542.

Pegler, D. N. 1997. The Larger Fungi of Borneo. Natural History Publications, Kota Kinabalu, Malaysia.

PEH K. S.-H., S. L. LEWIS, AND J. LLOYD. 2011. Mechanisms of monodominance in diverse tropical tree-dominated systems. J. Ecol. 99: 891-898.

PeYronel, B., AND B. FASSI. 1957. Micorrize ectotrofiche in una Caesalpinacea del Congo Belga. Atti Accad. Sci. Torino 91: 569-576.

Phosri, C., S. Põlme, A. F. S. TAYlor, U. Kõlualg, N. Suwannasai, And L. TEDERSOO. in press. Diversity and community composition of ectomycorrhizal fungi in a dry deciduous dipterocarp forest in Thailand. Biodivers. Conserv. 
Proctor, J., J. M. ANDERson, P. ChAi, AND H. W. VALLACK. 1983. Ecological studies

811

812

813

814

815

816

817

818

819

820

821

822

823

824

825

826

827

828

829

830

831

832

833 in four contrasting lowland rain forests in Gunung Mulu National Park, Sarawak. I. Forest environment, structure and floristics. J. Ecol. 71: 237-260.

READ, D. J. 1986. Non-nutritional effects of mycorrhizal infection. In V. GianinazziPearson and S. Gianiniazzi (Eds.) Physiological and Genetical Aspects of Mycorrhizae, pp. 169-176. INRA, Paris, France.

READ, D. J. 1998. Mycorrhiza - the state of the art. In A. Varma and B. Hock (Eds.). Mycorrhiza Structure, Function, Molecular Biology and Biotechnology, $2^{\text {nd }}$ Edition, pp. 3-34. Springer-Verlag, Berlin, Germany.

READ, D. J. 1999. The ecophysiology of mycorrhizal symbioses with special reference to impacts upon plant fitness. In M. C. Press, J. D. Scholes and M. G. Barker (Eds.). Physiological Plant Ecology, pp. 133-151. Blackwell Scientific, Oxford, UK.

REDECKER, D., T. M. SzARO, R. J. Bowman, AND T. D. BRuns 2001. Small genets of Lactarius xanthogalactus, Russula cremoricolor and Amanita francheti in latestage ectomycorrhizal successions. Mol. Ecol. 10: 1025-1034.

RiviÈRe, T., K. NATARAJAN, AND B. DREYFus. 2006. Spatial distribution of ectomycorrhizal Basidiomycete Russula subsect. Foetentinae populations in a primary dipterocarp rainforest. Mycorrhiza 16: 143-148.

Roy, M., S. Wattana, A. Stier, F. Richard, S. Vessabutr, and M.-A. Selosse 2009. Two mycoheterotrophic orchids from Thailand tropical dipterocarpaceaen forests associate with a broad diversity of ectomycorrhizal fungi. BMC Biol. 7: 51.

SANER, P. G. 2009. Ecosystem Carbon Dynamics in Logged Forests of Malaysian Borneo. Ph.D. Dissertation, University of Zurich, Switzerland. 
834 Saner, P. G., C. Philipson, R. C. Ong, N. Majalap, S. Egli, and A. Hector. 2011.

835 Positive effects of ectomycorrhizal colonization on growth of seedlings of a

836 tropical tree across a range of forest floor light conditions. Plant Soil, 338: 411-

$837 \quad 421$

838 SANTOSO, E. 1988. Pengaruh mikoriza terhadap diameter batang dan bobot kering

839 anakan Dipterocarpaceae. Bul. Penelit. Hutan (504): 11-21.

840 SANTOSO, E. 1991. Pengaruh beberapa fungi mikoriza terhadap penyerapan unsur hara

841 pada lima jenis Dipterocarpaceae. Bul. Penelit. Hutan (532): 11-18.

842 Shamsuddin, M. N. 1979. Mycorrhizas of tropical forest trees. In J. I. Furtado (Ed.).

843 Abstracts: Fifth International Symposium of Tropical Ecology, p. 173. University

844 of Malaya, Kuala Lumpur, Malaysia.

845 SHI, Z. Y., Y. L. CHEN, AND R. J. LIU. 2002. Preliminary survey on arbuscular

846 mycorrhizas of Dipterocarpaceae. Mycosystemia, 22: 82-87.

847 SHI, Z. Y., F. Y. WANG, Y. L. WEI, AND Y. L. CHEN. 2007. Observations on arbuscular

848 mycorrhizas on Dipterocarpaceae grown in tropical rainforest in China. Am.-

849 Eurasian J. Agric. Environ. Sci. 2: 247-254.

850 SHIVA, M. P., AND I. JANTAN. 1998. Non-timber forest products from dipterocarps. In S.

851 Appanah and J. M. Turnbull (Eds.). A Review of Dipterocarps: Taxonomy,

852 Ecology and Silviculture, pp. 187-197. Centre for International Forestry Research,

$853 \quad$ Bogor, Indonesia.

854 Simard, S. W., D. A. Perry, M. D. Jones, D. D. Myrold, D. M. Durall, And R.

855 MolinA. 1997. Net transfer of carbon between ectomycorrhizal tree species in the $856 \quad$ field. Nature 388: 579-582.

857 Sims, K. P., R. WATLING, AND P. JEFFries. 1995. A revised key to the genus

$858 \quad$ Scleroderma. Mycotaxon, 56: 403-420. 
SINGH, K. G. 1966. Ectotrophic mycorrhiza in equatorial rain forests. Malay. For. 29: $13-18$.

Sirikantaramas, S., N. Sugioka, S. S. Lee, L. A. Mohamed, H. S. Lee, A. E. Szmidt, AND T. YAMAZAKI. 2003. Molecular identification of ectomycorrhizal fungi associated with Dipterocarpaceae. Tropics 13: 69-77.

Slik, J. W. F., N. Raes, S.-I. Aiba, F. Q. Brearley, C. H. Cannon, E. MeijaArd, H. Nagamasu, R. Nilus, G. D. Paoli, A. D. Poulsen, D. Sheil, E. Suzuki, J. L. C. H. van Valkenburg, C. O. WebB, P. Wilkie, and S. WulfFraat. 2009. Environmental correlates for tropical tree diversity and distribution patterns in Borneo. Divers. Distrib. 15: 523-532.

SMITH, S. E., AND D. J. READ. 2008. Mycorrhizal Symbiosis, $3^{\text {rd }}$ Edition. Academic Press, San Diego, USA.

SMITS, W. T. M. 1983. Dipterocarps and mycorrhiza - an ecological adaptation and a factor in forest regeneration. Flora Males. Bull. 36: 3926-3937.

SMITs, W. T. M. 1985. Specificity of dipterocarp mycorrhiza. In R. Molina (Ed.). Proceedings of the $6^{\text {th }}$ North American Conference on Mycorrhizae, p. 364. Forest Research Laboratory, Corvallis, Oregon, USA.

SMITS, W. T. M. 1994. Dipterocarpaceae: Mycorrhizae and Regeneration. The Tropenbos Foundation, Wageningen, The Netherlands.

ST. John, T. V. 1980. A survey of mycorrhizal infection in an Amazonian rain forest. Acta Amazon. 10: 527-533.

SUHARDI. 2000. Treatment to development mycorrhizal formation on dipterocarp seedlings. In E. Guhardja, M. Fatawi, M. Sutisna, T. Mori and S. Ohta (Eds.) Rainforest Ecosystems of East Kalimantan: El Niño, Drought, Fire and Human Impacts, Ecological Studies 140. pp. 245-250. Springer-Verlag, Tokyo, Japan. 
884 SuHARDI, A. DARMAWAN, AND E. FARIDAH. 1993. Effect of shading, fertilizer and 885 mulching with alang-alang to the early growth and mycorrhiza formation of 886 Shorea bracteolata in Bukit Suharto. In Anon. (Ed.). BIO-REFOR: Proceedings of Tsukuba-Workshop, pp. 161-173. BIO-REFOR, IUFRO-SPDC, Tsukuba Science City, Japan.

TAtA, M. H. L., S. HAdi, C. KusmanA, AND ACHMAD (2003) Effect of forest fire on the 890 survival of ectomycorrhizal fungi on dipterocarps. In H. Aminah, S. Ani, H. C. Sim and B. Krishnapillay (Eds.). Proceedings of the Seventh Round-Table Conference on Dipterocarps. 7-10 October 2002, pp. 173-178. Asia Pacific Association of Forestry Research Institutions. Kuala Lumpur, Malaysia.

TATA M. H. L., M. VAn NoOrdwiJk, R. Summerbell, AND M. J. A. Werger. 2010. Limited response to nursery-stage mycorrhiza inoculation of Shorea seedlings planted in rubber agroforest in Jambi, Indonesia. New For. 39: 51-74. effort and species detection. Plant Soil 244: 19-28.

Tawaraya, K., Z. TAKaya, M. Turjaman, S. J. Tuah, S. H. Limin, Y. TAmai, J. Y. Cha, T. WAgAtsuma, AND M. OsAKI. 2003. Arbuscular mycorrhizal colonization of tree species grown in peat swamp forests of Central Kalimantan, Indonesia. For. Ecol. Manage. 182: 381-386.

TEDERSOO, L., AND K. NARA. 2010. General latitudinal gradient of biodiversity is reversed in ectomycorrhizal fungi. New Phytol. 185: 351-354.

905 Tedersoo, L., T. Suvi, K. BeAVER, AND U. KõLJAlg. 2007a. Ectomycorrhizal fungi on 906 the Seychelles: diversity patterns and host shifts from the native Vateriopsis seychellarum (Dipterocarpaceae) and Intsia bijuga (Caesalpinaceae) to the 
introduced Eucalyptus robusta (Myrtaceae) but not Pinus caribaea (Pinaceae). New Phytol. 175: 321-333.

910

911

912

913

914

915

916

917

918

919

920

921

922

923

924

925

926

927

928

929

930

931

932

Tedersoo, L., T. Suvi, K. BeAver, AND I. SAAR. 2007b. Ectomycorrhizas of Coltricia and Coltriciella (Hymenochaetales, Basidiomycota) on Caesalpiniaceae, Dipterocarpaceae and Myrtaceae in Seychelles. Mycol. Prog. 6: 101-107.

Tedersoo, L., T. W. MAY, AND M. E. SMIth. 2010. Ectomycorrhizal lifestyle in fungi: global diversity, distribution, and evolution of phylogenetic lineages. Mycorrhiza 20: $217-263$.

Tedersoo, L., M. Bahram, T. Jairus, E. Bechem, S. Chinoya, R. Mpumba, M. Leal, E. RANDRIANJOHANY, S. RAZAFIMANDIMBISON, A. SADAM, T. NAADEL, AND U. KõLJALG. 2011. Spatial structure and the effects of host and soil environments on communities of ectomycorrhizal fungi in wooded savannas and rain forests of Continental Africa and Madagascar. Mol. Ecol. 20: 3071-3080.

Tennakoon, M. M. D., I. A. U. N. Gunatilleke, K. M. Hafeel, G. Seneviratne, C. V. S. GunAtILlEKe, AND P. M. S. Ashton. 2005. Ectomycorrhizal colonization and seedling growth of Shorea (Dipterocarpaceae) species in simulated shade environments of a Sri Lankan rain forest. For. Ecol. Manage. 208: 399-405.

TRESEDER, K. K. 2004. A meta-analysis of mycorrhizal responses to nitrogen, phosphorus and atmospheric $\mathrm{CO}_{2}$ in field studies. New Phytol. 164: 347-355.

TUPAS, G. L., AND P. E. SAJISE. 1976. Mycorrhizal associations in some savanna and reforestation trees. Kalikasan 5: 235-240.

Turjaman, M., Y. Tamai, H. Segah, S. H. Limin, J. Y. Cha, M. Osaki, and K. TAWARAYA. 2005. Inoculation with the ectomycorrhizal fungi Pisolithus arhizus and Scleroderma sp. improves early growth of Shorea pinanga nursery seedlings. New For. 30: 67-73. 
Turjaman, M., Y. TAmai, H. Segah, S. H. Limin, M. Osaki, And K. TAwaraya. 2006.

934

935

936

937

938

939

940

941

942

943

944

945

946

947

948

949

950

951

952

953

954

955

956

957 Increase in early growth and nutrient uptake of Shorea seminis inoculated with two ectomycorrhizal fungi. J. Trop. For. Sci. 18: 243-249.

Turjaman, M., H. Saito, E. Santoso, A. Susanto, S. Gaman, S. H. Limin, M. ShiBUYA, K. TAKAHASHI, Y. TAMAI, M. OSAKI, AND K. TAWARAYA. 2007. Effect of ectomycorrhizal fungi inoculated on Shorea balangeran under field conditions in peat-swamp forests. In J. O. Rieley, C. J. Banks and B. Radjagukguk (Eds.). Proceedings of the International Symposium and Workshop on Tropical Peatland, Yogyakarta, 27-29 August 2007, pp 143-148. CARBOPEAT, University of Leicester, UK.

Turner, I. M., N. D. Brown, AND A. C. NEWTON. 1993. The effect of fertilizer addition on dipterocarp seedling growth and mycorrhizal infection. For. Ecol. Manage. 57: 329-337.

VAN DER HEIJDEN, M. G. A., AND I. R. SANDERS, I. R. 2002. Mycorrhizal Ecology, Ecological Studies 157. Springer-Verlag, Berlin, Germany.

VAn GARdingen, P. R., M. J. Clearwater, T. Nifinluri, R. EFFEndi, W. Rusmantoro, M. Noor, P. A. Mason, K. Ingleby, And R. C. Munro. 1998. Impacts of logging on the regeneration of lowland dipterocarp forest in Indonesia. Commonw. For. Rev. 77: 71-82.

VAn RoOSEndAel, J., AND A. THORENAAR. 1924. De natuurlijke verjonging van Ngerawan (Hopea mengarawan Miq.) in zuid Sumatra. Tectona, 16: 519-567.

WATLING, R., AND S. S. LEE. 1995. Ectomycorrhizal fungi associated with members of the Dipterocarpaceae in Peninsular Malaysia - I. J. Trop. For. Sci. 7: 657-669.

WATLING, R., AND S. S. LEE. 1998. Ectomycorrhizal fungi associated with members of the Dipterocarpaceae in Peninsular Malaysia - II. J. Trop. For. Sci. 10: 421-430. 
958

959

960

961

962

963

964

965

966

967

968

969

970

971

972

973

974

975

976

977

978

979

980

981

982

WATLING, R., AND S. S. LEe. 2007. Mycorrhizal mycodiversity in Malaysia. In E. B. G. Jones, K. D. Hyde and S. Vikineswary (Eds.). Malaysian Fungal Diversity, pp. 201 219. Mushroom Research Centre, University of Malaya \& Ministry of Natural Resources and Environment, Kuala Lumpur, Malaysia,

Watling, R., A. F. S. TAylor, S. S. Lee, K. Sims, And I. J. AleXAnder. 1995a. A rainforest Pisolithus; its taxonomy and ecology. Nova Hedwig. 61: 417-429.

WAtling, R, S. S. LeE, AND E. TuRnBull. 1998. Putative ectomycorrhizal fungi of Pasoh Forest Reserve, Negri Sembilan, Malaysia. In S. S. Lee, Y. M. Dan, I. D. Gauld and J. Bishop (Eds.). Conservation, Management and Development of Forest Resources, pp. 96-104. Forest Research Institute of Malaysia, Kepong, Malaysia.

WATLing, R, S. S. LEe, AND E. TURnBULL. 2002. The occurrence and distribution of putative ectomycorrhizal basidiomycetes in a regenerating south-east Asian rainforest. In R. Watling, J. C. Frankland, A. M. Ainsworth, S. Isaac and C. H. Robinson (Eds.). Tropical Mycology: Volume 1 Macromycetes, pp. 25-43. CAB International, Wallingford, UK.

WATling, R., S. S. LEe, AND E. TuRnBULL. 2006. Notes taxonomiques et floristiques sur quelques bolets tropicaux et groupes proches. Bull. Soc. Mycol. Fr. 122: 327352.

YASMAN, I. 1995. Dipterocarpaceae Tree-Mycorrhizae-Seedling Connections. Ph.D. Thesis, Wageningen Agricultural University, The Netherlands.

YAZID, S. M., S. S. LEE, AND F. F. LAPEYRIE. 1994. Growth stimulation of Hopea spp. (Dipterocarpaceae) seedlings following mycorrhizal inoculation with an exotic strain of Pisolithus tinctorius. For. Ecol. Manage. 67: 339-343.

YAZID, S. M., S. S. LEE, AND F. F. LAPEYRIE. 1996. Mycorrhizal inoculation of Hopea odorata (Dipterocarpaceae) in the nursery. J. Trop. For. Sci. 9: 276-278. 
983 Yuwa-Amornpitak, T., T. Vichitsoonthonkul, M. TANTicharoen, S.

984 ChEEVADHANARAK, AND S. RATCHADAWONG. 2006. Diversity of ectomycorrhizal

985 fungi on Dipterocarpaceae in Thailand. J. Biol. Sci. 6: 1059-1064.

986

987 
988 FIGURE 1. Ectomycorrhizas formed by A) Scleroderma species, B) Inocybe species

989 and C) Thelephorales species on roots of various member of the Dipterocarpaceae

990 (Photograph C by Götz Palfner).

991

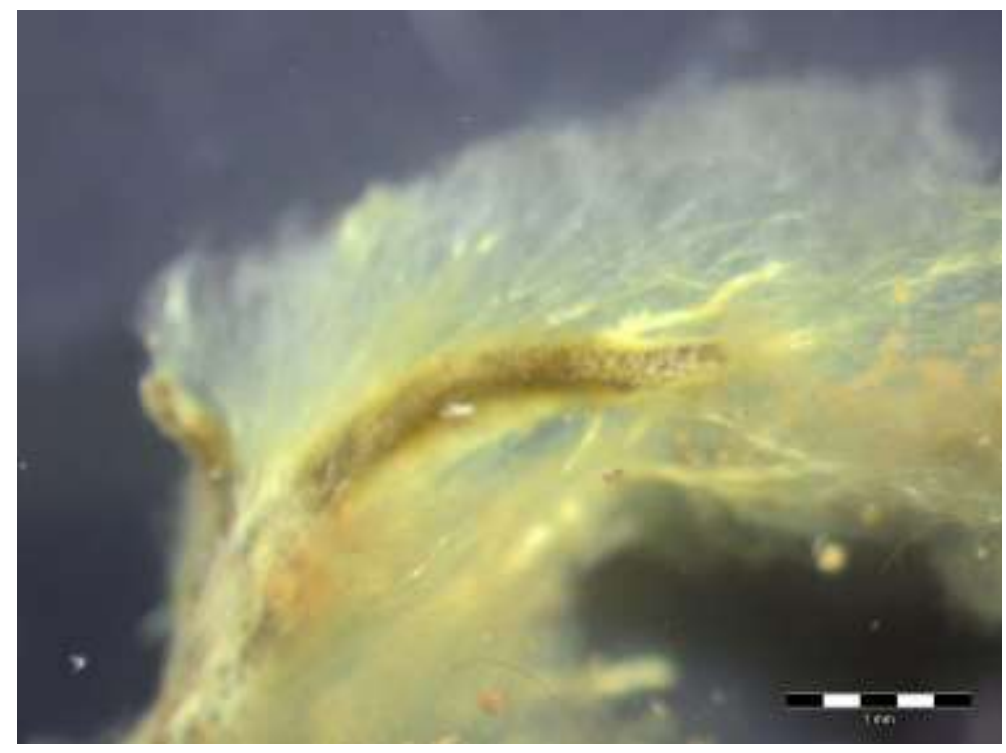

992
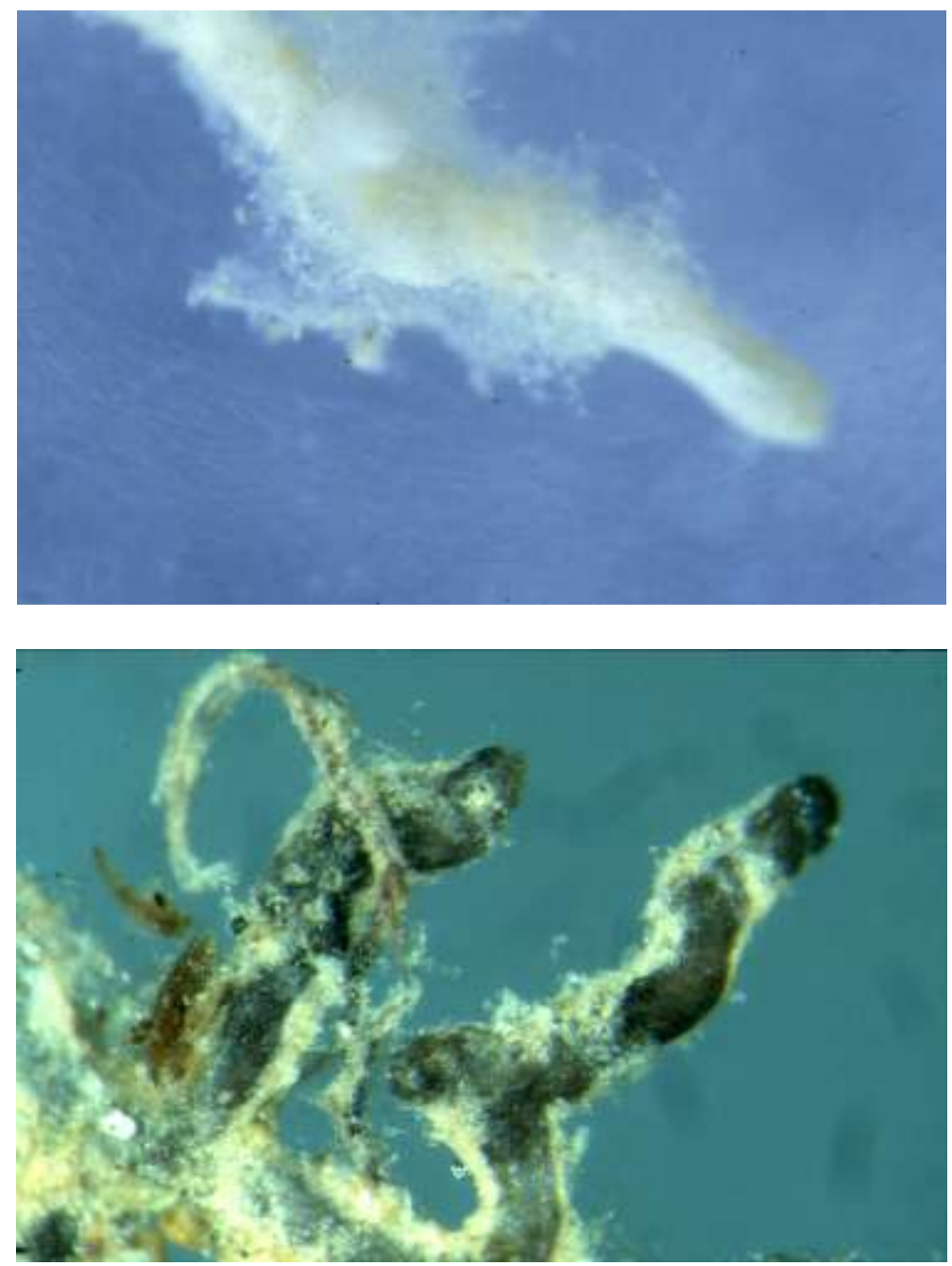
TABLE 1. Molecular identification of ectomycorrhizas associated with Dipterocarpaceae hosts in a number of studies. All values are the percentage of sequences found within the particular fungal lineage (taxonomic nomenclature follows Tedersoo et al. 2010). Note that studies are not strictly comparable due to different primer pairs used to amplify fungal DNA.

\begin{tabular}{|c|c|c|c|c|c|c|c|c|}
\hline & $\begin{array}{l}\text { Malaysia (Five } \\
\text { sites) }\end{array}$ & $\begin{array}{l}\text { Venezuela } \\
\text { (Pakaraimea } \\
\text { dipterocarpacea) }\end{array}$ & $\begin{array}{l}\text { Thailand (Eight } \\
\text { sites) }\end{array}$ & $\begin{array}{l}\text { Seychelles } \\
\text { (Vateriopisis } \\
\text { seychellarum) }\end{array}$ & $\begin{array}{l}\text { Sarawak (Lambir } \\
\text { Hills) }\end{array}$ & Sumatra (Jambi) & $\begin{array}{l}\text { Thailand } \\
\text { (Phitsanulok) }\end{array}$ & $\begin{array}{l}\text { Kalimantan } \\
\text { (Bukit Bangkirai) }\end{array}$ \\
\hline & $\begin{array}{l}\text { Sirikantaramas et } \\
\text { al. } 2003\end{array}$ & Moyersoen 2006 & $\begin{array}{l}\text { Yuwa- } \\
\text { Amornpitak et al. } \\
2006\end{array}$ & $\begin{array}{l}\text { Tedersoo et al. } \\
2007 \mathrm{a}\end{array}$ & Peay et al. 2010 & Tata et al. 2010 & $\begin{array}{l}\text { Phosri et al. in } \\
\text { press }\end{array}$ & Nara pers. comm. \\
\hline Ascomycota & - & - & - & - & - & - & - & 3 \\
\hline Elaphomycetales & - & - & - & - & 1 & - & 4 & - \\
\hline Helotiales & - & - & - & - & 1 & - & - & - \\
\hline Pezizales & - & - & - & - & - & - & 3 & - \\
\hline Sordariales & - & - & - & 11 & 5 & - & 6 & - \\
\hline Basidiomycota & - & - & - & - & - & - & - & - \\
\hline Agaricales & - & - & 3 & - & 3 & - & - & - \\
\hline /amanita & 1 & 11 & 3 & - & 3 & - & 3 & 6 \\
\hline /cortinarius & 1 & 11 & - & 11 & 10 & - & - & 6 \\
\hline /hygrophorus & 1 & - & - & - & - & - & - & - \\
\hline /inocybe & - & 22 & 9 & 6 & - & - & 4 & 2 \\
\hline
\end{tabular}




\begin{tabular}{|c|c|c|c|c|c|c|c|c|}
\hline /laccaria & - & - & - & - & - & - & 1 & - \\
\hline Atheliales & - & - & - & - & 3 & - & 1 & - \\
\hline Boletales & - & - & - & - & 5 & - & - & 15 \\
\hline /boletus & 17 & - & 6 & 6 & 11 & - & 1 & - \\
\hline $\begin{array}{l}\text { pisolithus- } \\
\text { scleroderma }\end{array}$ & 10 & - & 21 & 6 & 2 & 25 & 3 & - \\
\hline Cantharellalaes & - & - & - & - & 3 & - & - & 11 \\
\hline /cantharellus & 2 & - & - & 6 & 3 & 8 & 4 & - \\
\hline /clavulina & - & 22 & - & - & 6 & 8 & 3 & - \\
\hline Hymenochaetales & - & - & - & 17 & 2 & - & - & - \\
\hline Hysterangiales & - & - & - & - & 1 & - & - & - \\
\hline Russulales & 16 & - & 18 & 6 & 28 & - & 32 & 31 \\
\hline Sebacinales & - & 11 & - & - & 2 & 8 & 6 & 2 \\
\hline Thelephorales & 51 & - & 36 & 33 & 12 & 50 & 25 & 25 \\
\hline Unidentified & - & 22 & 3 & - & - & - & - & - \\
\hline
\end{tabular}

